\title{
Effects of Particle Size of Alfalfa-Based Dairy Cow Diets on Site and Extent of Digestion ${ }^{1}$
}

\author{
W. Z. Yang, K. A. Beauchemin, and L. M. Rode \\ Livestock Sciences Section, Research Centre \\ Agriculture and Agri-Food Canada, \\ Lethbridge, AB, T1J 4B1, Canada
}

\section{ABSTRACT}

Effects of ratio of alfalfa silage to alfalfa hay and forage particle size on nutrient intakes, site of digestion, rumen pools, and passage rate of ruminal contents were evaluated in a $4 \times 4$ Latin square design with a $2 \times 2$ factorial arrangement of treatments. The diets consisted of $60 \%$ barley-based concentrate and $40 \%$ forage made up either of 50:50 or 25:75 of alfalfa silage:alfalfa hay and alfalfa hay was either chopped or ground. Lactating dairy cows surgically fitted with ruminal and duodenal cannulas were used and offered ad libitum access to a total mixed ration. Intakes of nutrients were increased by increasing ratio of silage to hay but were not affected by particle size of forage. Change in ratio of silage to hay of diets did not affect site and extent of digestion. However, increased forage particle size of the diets improved digestibility of fiber and $\mathrm{N}$ in the total tract, and as well as digestibility of organic matter, starch, and acid detergent fiber in the intestine. There was a shift of starch digestion from the rumen to the intestine when forage particle size was increased, although total digestion of starch was not changed. Ruminal microbial protein synthesis and microbial efficiency also improved with increasing forage particle size. Cows fed ground hay versus chopped hay had significantly lower rumen wet mass regardless of the ratio of silage to hay. Reduced forage particle size also lowered ruminal nutrient pool size for cows fed the high silage diet. Ruminal passage rates of liquid and solid were decreased by reducing the ratio of silage to hay, and retention time of solids in the total tract was shortened by reducing forage particle size. These results indicate that manipulating ratio of silage to hay in the diets of dairy cows changed feed intake but had little effect on digestion. In contrast, increased forage particle size in dairy cow diets improved fiber digestion and microbial

Received October 3, 2001.

Accepted November 28, 2001.

Corresponding author: K. A. Beauchemin; e-mail: beauchemin @em.agr.ca.

${ }^{1}$ Contribution number: 38701058. protein synthesis in the rumen, and shifted starch digestion from the rumen to the intestine. Dietary particle size, expressed as physically effective neutral detergent fiber, was a reliable indication of ruminal microbial protein synthesis and nutrient digestion.

(Key words: ratio of alfalfa silage to hay, physically effective neutral detergent fiber, site of digestion, dairy cow)

Abbreviation key: $\mathbf{A H}=$ alfalfa hay, $\mathbf{A S}=$ alfalfa silage, AS:AH = ratio of alfalfa silage to alfalfa hay, FPS = forage particle size, $\mathbf{p e N D F}=$ physically effective NDF, PSPS $=$ Penn State Particle Separator.

\section{INTRODUCTION}

Current dietary guidelines for lactating dairy cows indicate that the physical form of the diet is important in determining its nutritive value, affecting chewing activities, DMI, rumen function, digestive efficiency, milk production and composition, and health of the cow (Allen, 1997). The physical form of specific feeds is usually quantitatively assessed by various sieving methods (Murphy and Zhu, 1997). However, the variety of methods employed has made it difficult to compare results from different laboratories or compile such data into a form that is useful for diet formulation. Recently, the concept of physically effective fiber (peNDF) was introduced (Mertens, 1997) to relate the physical characteristics of feeds to rumen $\mathrm{pH}$ by measuring particle length or chewing activity. Two different systems exist that attempt to quantify peNDF. Mertens (1997) suggested using the NDF of forage retained on a 1.18-mm screen while another system is based on the NDF content of three different particle size fractions using the Penn State Particle Separator (PSPS, Lammers et al., 1996). Although several studies related to peNDF have been published (Beauchemin et al., 2002; Yang et al., 2001), none of these systems has been adequately validated and there is very limited information to establish the requirements of peNDF for dairy cows and to determine the peNDF values of feeds. In addition, most of those studies have focused on the effects of dietary particle size on chewing activity, ruminal $\mathrm{pH}$, or milk produc- 
tion and composition. Little information is available in the literature regarding feed digestion, especially for site of digestion associated with peNDF content of the dairy cow diet (Yang et al., 2001).

Digestibility of nutrients is an important parameter of feed quality. The physical changes of feeds such as its particle size could affect rumen digestion, passage rate, and microbial protein synthesis, and thus postruminal or total digestion. Rode et al. (1985) reported that efficiency of ruminal microbial protein synthesis increased by $15 \%$ and digestion of $\mathrm{N}$ in the rumen or in the total tract was significantly improved when ground hay replaced long hay in the diet of dairy cows. Furthermore, alfalfa forage, conserved as silage (AS) or hay (AH), is a major component of diets fed to lactating dairy cows. Supplementation of AS-based diets with $\mathrm{AH}$ is beneficial for increasing milk production as a result of increasing ruminating time, improving rumen environment, and therefore digestion of nutrients (Beauchemin and Buchanan-Smith, 1989). The objectives of this study were to evaluate the effects of forage particle size (FPS) and ratio of alfalfa silage to hay (AS:AH) on nutrient intake, site of digestion, rumen digesta pools and passage rate in dairy cows.

\section{MATERIALS AND METHODS}

\section{Cows and Diets}

Four lactating Holstein cows that were surgically fitted with ruminal and duodenal cannulas were used. The ruminal cannulas measured $10 \mathrm{~cm}$ in diameter and were constructed of soft plastic (Bar Diamond, Parma, ID). Duodenal cannulas were T-shaped and were placed proximal to the common bile and pancreatic duct, approximately $10 \mathrm{~cm}$ distal to the pylorus. At the start of the experiment, the cows averaged $655 \pm 79 \mathrm{~kg}$ of BW and $127 \pm 38$ DIM and were housed in individual tie stalls and offered a TMR ad libitum three times daily at 0800,1500 , and $1800 \mathrm{~h}$. Cows were cared for according to the Canadian Council on Animal Care Guidelines (Ottawa, ON, Canada).

The experimental design was a $4 \times 4$ Latin square with four 21 -d periods and a $2 \times 2$ factorial arrangement of treatments: AS:AH (high vs. low, 50:50 vs. 25:75) combined with particle size of the hay. The diets were formulated using the Cornell-Penn-Miner System (CPMDairy, Version 1.0) to supply adequate metabolizable energy and metabolizable protein for a $650-\mathrm{kg}$ cow producing $30 \mathrm{~kg} / \mathrm{d}$ of milk with $3.5 \%$ fat and $3.2 \%$ protein (Table 1). The diets consisted of $60 \%$ barley-based concentrate and $40 \%$ forage. Each period consisted of $11 \mathrm{~d}$ of adaptation to diets and $10 \mathrm{~d}$ of experimental measurements consisting of feed intake, pool size of rumen contents, rate of passage, and site and extent of digestion.

Barley grain obtained from one source was used throughout the experiment. The barley was first screened to remove chaff and small kernels and then steam-rolled to an optimum degree of rolling for dairy cows as described by Yang et al. (2000). This corresponded to a processing index, measured as ratio of the volume weight of the barley after processing to its volume weight before processing, of $65 \%$. Alfalfa silage and $\mathrm{AH}$ also obtained from one source were used throughout the experiment. Differences in mean particle length and the physically effective factor (Mertens, 1997) of the diets were created by manipulating the AS:AH and particle size of the AH (Beauchemin et al., 2002). The $\mathrm{AH}$ was either chopped or ground through a $4-\mathrm{mm}$ screen.

Feed offered and orts were measured and recorded daily during the last $10 \mathrm{~d}$ of the period to calculate feed intake. Feed samples were collected once weekly, and orts were collected twice weekly for DM determination. Samples were ground through a 1-mm diameter screen (standard model 4, Arthur Thomas Co., Philadelphia, $\mathrm{PA}$ ) and composited by period for analysis of OM, NDF, $\mathrm{ADF}$, starch, and $\mathrm{CP}$.

\section{Rate of Passage and Rumen Pool Size}

Ruminal digesta kinetics were measured using Crmordanted NDF and Co-EDTA as forage and liquid markers, respectively. Fiber from AS, chopped or ground AH was separately prepared by repeatedly soaking in dilute detergent and rinsing in a washing machine until the NDF content of the material exceeded $80 \%$. The fiber was then dried at $55^{\circ} \mathrm{C}$. Methods used to mordant $\mathrm{Cr}$ to plant cell walls and to prepare CoEDTA were those of Udén et al. (1980). An amount of $250 \mathrm{~g}$ of Cr-mordanted NDF that was proportionally and physically composited to be identical to the forages fed to cows, and $300 \mathrm{ml}$ of solution containing $15 \mathrm{~g}$ of Co-EDTA were introduced in the rumen via the ruminal cannulas. Fecal samples were collected from the rectum at $6,9,12,15,18,24,32,48,72,96$, and $120 \mathrm{~h}$ after dosing with the markers. The particles were dried at $55^{\circ} \mathrm{C}$, ground through a $1-\mathrm{mm}$ diameter screen (standard model 4), and stored for $\mathrm{Cr}$ and $\mathrm{Co}$ analyses. Kinetics of liquid and particle passage were estimated for each cow and period from concentrations of $\mathrm{Co}$ and $\mathrm{Cr}$ in fecal samples, respectively. A double compartmental model represented by two exponential constants and a time delay (Grovum and Williams, 1973) was fitted using the nonlinear regression procedure of SAS (1996).

Ruminal contents were manually emptied from each cow at $1030 \mathrm{~h}$ on the last day of the period. The total 
Table 1. Ingredients and chemical composition of the total mixed diet (DM basis).

\begin{tabular}{|c|c|c|}
\hline \multirow[b]{2}{*}{ Item } & \multicolumn{2}{|c|}{ Diets (alfalfa silage:alfalfa hay } \\
\hline & $50: 50$ & $25: 75$ \\
\hline \multicolumn{3}{|l|}{ Ingredients } \\
\hline Alfalfa silage ${ }^{1}$ & 19.7 & 10.2 \\
\hline Alfalfa hay ${ }^{1}$ & 19.7 & 29.5 \\
\hline Steam-rolled barley grain ${ }^{1}$ & 46.1 & 45.5 \\
\hline Corn gluten meal & 3.01 & 1.94 \\
\hline Heat-treated canola meal (Alberta Gold ${ }^{\mathrm{TM}}$ ) & 1.70 & 2.66 \\
\hline Soybean meal & 4.51 & 4.36 \\
\hline Beet molasses & 0.97 & 0.97 \\
\hline Urea & $\ldots$ & 0.29 \\
\hline Calcium carbonate & 0.78 & 0.77 \\
\hline Dicalcium phosphate & 0.39 & 0.39 \\
\hline Monophosphate & 0.29 & 0.29 \\
\hline Vitamin and mineral premix ${ }^{2}$ & 1.94 & 1.94 \\
\hline Canola oil & 0.82 & 0.97 \\
\hline Binding agent $\left(\mathrm{Aka}^{\mathrm{TM}}\right)$ & 0.19 & 0.19 \\
\hline \multicolumn{3}{|l|}{ Chemical } \\
\hline DM & 68.3 & 77.6 \\
\hline $\mathrm{OM}$ & 91.4 & 91.3 \\
\hline $\mathrm{CP}$ & 18.0 & 18.5 \\
\hline $\mathrm{NDF}$ & 36.1 & 36.0 \\
\hline NDF from forages & 19.5 & 18.6 \\
\hline Starch & 29.5 & 28.7 \\
\hline $\mathrm{NE}_{\mathrm{L}}, \mathrm{Mcal} / \mathrm{kg}^{3}$ & 1.58 & 1.59 \\
\hline
\end{tabular}

${ }^{1}$ Chemical composition of alfalfa silage, alfalfa hay, and barley grain (DM basis) was $89.8,90.8$, and $97.7 \%$ for OM; 55.2, 52.3, and 25.2\% for NDF; 48.0, 42.5, and 6.7\% for ADF; 16.6, 17.7, and 13.9\% for CP, respectively.

${ }^{2}$ Contained $51.97 \% \mathrm{NaCl}, 35.98 \%$ Dynamate (Pitman Moore, Inc., Mundelein, IL); $18 \% \mathrm{~K}, 11 \% \mathrm{Mg}, 22 \%$ $\mathrm{S}, 1000 \mathrm{mg} \mathrm{Fe} / \mathrm{kg}), 2 \% \mathrm{ZnSO}_{4} \cdot \mathrm{H}_{2} \mathrm{O}, 2.4 \% \mathrm{MnSO}_{4} \cdot 4 \mathrm{H}_{2} \mathrm{O}, 0.01 \% \mathrm{CoSO}_{4} \cdot 6 \mathrm{H}_{2} \mathrm{O}, 0.009 \% \mathrm{Na}_{2} \mathrm{SeO}_{3}, 0.012 \%$ ethylenediamine dihydroiodide, $0.8 \% \mathrm{CuSO}_{4} \cdot 5 \mathrm{H}_{2} \mathrm{O}, 680,000 \mathrm{IU} / \mathrm{kg}$ of vitamin $\mathrm{A}, 160,000 \mathrm{IU} / \mathrm{kg}$ of vitamin $\mathrm{D}$ and $2000 \mathrm{IU} / \mathrm{kg}$ of vitamin $\mathrm{E}$.

${ }^{3}$ Estimated from NRC (1989).

ruminal mass was determined by weighing. After thorough mixing, four 1-kg samples were removed. Two of the samples were used to determine DM content by oven-drying at $55^{\circ} \mathrm{C}$ for $48 \mathrm{~h}$, and the other two samples were immediately separated into liquid and solid phases by squeezing through four layers of cheesecloth to determine proportion of liquid. A portion of dried samples was ground through a 1-mm diameter screen (standard model 4) for chemical analysis.

\section{Duodenal Flow and Apparent Digestion}

Duodenal flow and apparent digestion of nutrients at the different sites of the digestive tract were determined using $\mathrm{YbCl}_{3}$ (Rhône-Poulenc Inc., Shelton, CT). Ammonia ${ }^{15} \mathrm{~N}\left(\left[{ }^{15} \mathrm{NH}_{4}\right]_{2} \mathrm{SO}_{4}, 10.6 \%\right.$ atom $\%{ }^{15} \mathrm{~N}$; Isotec, Miamisburg, $\mathrm{OH}$ ) was used as a ruminal microbial marker. Marker solution was continuously infused into the rumen via ruminal cannulas using an automatic pump (model 60 RPM/7524-10, Masterflex L/S Microprocessor pump drive, Vernon Hills, IL) during the last $11 \mathrm{~d}$ of the period. Daily amounts infused were $2.6 \mathrm{~g}$ of $\mathrm{Yb}$ and $140 \mathrm{mg}$ of ${ }^{15} \mathrm{~N}$ dissolved in $800 \mathrm{ml}$ of water for each cow. Ruminal, duodenal, and fecal samples were collected four times daily every $6 \mathrm{~h}$, moving ahead $2 \mathrm{~h}$ each day for the last $3 \mathrm{~d}$ of infusion. This schedule provided 12 representative samples of ruminal, duodenal, and fecal contents taken at 2-h intervals.

Ruminal samples were immediately squeezed through four layers of cheesecloth. Ruminal particles obtained by squeezing were blended ( $400 \mathrm{~g}$ of particles plus $400 \mathrm{ml}$ of $0.9 \% \mathrm{NaCl}$ ) in a Waring blender (Waring Products Division, New Hartford, CT) for $1 \mathrm{~min}$ and then squeezed through four layers of cheesecloth. Both filtrates from squeezed and strained homogenate were mixed, centrifuged $\left(800 \times g\right.$ for $10 \mathrm{~min}$ at $\left.4^{\circ} \mathrm{C}\right)$ to remove protozoa and feed particles, and the supernatant was centrifuged $\left(27,000 \times \mathrm{g}\right.$ for $30 \mathrm{~min}$ at $\left.4^{\circ} \mathrm{C}\right)$ to obtain a mixed ruminal bacteria pellet. Bacterial isolates were accumulated by period, freeze-dried, and ground using a mortar and pestle. Subsamples of the ground bacterial composites were further ground using a ball mill (Mixer Mill MM2000; Retsch, Haan, Germany) to a fine powder for determination of $\mathrm{N}$ content and ${ }^{15} \mathrm{~N}$ enrichment.

Duodenal samples were pooled by cow for each period using a mixer (model MX-9100, Toshiba, Tokyo, Japan) and freeze-dried for chemical analysis. Fecal samples were also pooled by cow for each period, dried at $55^{\circ} \mathrm{C}$ 
and ground through a 1-mm screen (standard model 4) for chemical analyses.

\section{Chemical Analyses}

Feed DM was determined by oven-drying at $55^{\circ} \mathrm{C}$ for $48 \mathrm{~h}$. Analytical DM content of the samples was determined by drying at $135^{\circ} \mathrm{C}$ for $3 \mathrm{~h}$ (AOAC, 1990). The OM content was calculated as the difference between DM and ash contents, with ash determined by combustion at $550^{\circ} \mathrm{C}$ overnight. The NDF and ADF contents were determined using the methods described by Van Soest et al. (1991) with amylase and sodium sulfite used in the NDF procedure. Starch was determined by enzymatic hydrolysis of $\alpha$-linked glucose polymers as described previously (Rode et al., 1999). Contents of $\mathrm{Cr}$ and $\mathrm{Co}$ in the samples were determined using atomic absorption spectrophotometry according to the AOAC (1990). The content of CP in the samples and enrichment of ${ }^{15} \mathrm{~N}$ in the bacteria isolated from the rumen and in duodenal digesta was determined by flash combustion (Carlo Erba Instruments, Milan, Italy) with isotope ratio mass spectrometry (VG Isotech, Middlewich, England). The determination of particle size distributions of the TMR was outlined in a previous study (Beauchemin et al., 2002).

\section{Calculations and Statistical Analyses}

Flows of DM to the duodenum and DM excreted in feces were calculated by dividing $\mathrm{Yb}$ infused ( $\mathrm{g}$ of $\mathrm{Yb}$ per day) by $\mathrm{Yb}$ concentration ( $\mathrm{g}$ of $\mathrm{Yb}$ per kilogram of DM) in the duodenal digesta or feces, respectively. Flows of other nutrients to the duodenum or feces were calculated by multiplying DM flow by their concentration in duodenal or fecal DM. Ruminal microbial protein synthesis for each cow was estimated by the ratio of ${ }^{15} \mathrm{~N}$ flow at the duodenum to ${ }^{15} \mathrm{~N}$ concentration of mixed ruminal bacteria. Kinetics of liquid and forage passage from the rumen were estimated using the nonlinear regression procedure of SAS (1996) for each cow and period from Co and $\mathrm{Cr}$ concentrations in ruminal samples, respectively.

For each period, means for individual cows were calculated for all variables. Data were analyzed using the mixed model procedure of SAS (Proc Mixed; SAS, 1996). The AS:AH, FPS, and their two-way interaction were considered fixed effects; period and cow were considered random effects. Estimation method was REML, and the degrees of freedom method was Kenward-Rogers. Pearson correlation coefficients were estimated using the CORR procedure of SAS (SAS, 1996). Effects of the factors were declared significant at $P<0.05$ unless otherwise noted, and trends were discussed at $P<0.15$.

\section{RESULTS AND DISCUSSION}

\section{Intake, Duodenal Flow, and Site of Digestion}

Organic matter. Intake of OM was decreased $(P<$ $0.07)$ by $13.4 \%$ with decreased AS:AH but was not affected by FPS (Table 2). Flow of OM to the duodenum and its digestibility in the rumen, the intestine or the total tract were not affected by the treatments. Thus, the trend toward more OM fermented in the rumen $(P$ $<0.06)$ and excreted in the feces $(P<0.14)$ with high silage than with low silage diets was likely due to higher intake of OM. Higher OM intake for cows fed the high silage diet is in agreement with Nelson and Satter (1992a) but opposite to another study (Nelson and Satter, 1992b). Clancy et al. (1977) reported that the moisture content of AS was beneficial, as cows consumed less DM when dried AS was fed than when wet hay was fed. However, those studies were conducted using cows fed AS or AH as the sole forages. In fact, Beauchemin et al. (1994) observed that intake of DM was quadratically increased when AS:AH in the diet of cows varied from 100:0, 70:30 to 43:57 in diets containing $47 \%$ forage (DM basis).

Lack of effect of FPS on OM intake confirms the results of others (Belyea et al., 1989; Grant et al., 1990). Feed intake is influenced by digestion rate and passage rate of feeds in the rumen. When high quality forages are fed, particle size reduction may not be a rate-limiting step for particulate passage because reduction of particle size through ingestive mastication and rumination may be very rapid (Shaver et al., 1988). Furthermore, increasing particle size of feeds usually promotes chewing activity (Beauchemin and Buchanan-Smith, 1989; Grant et al., 1990).

Failure to establish effects of AS:AH on digestibility of OM at the different sites of the digestive tract is in agreement with Phuntsok et al. (1998) but opposite to others (Nelson and Satter, 1992a; Broderick, 1995). Phuntsok et al. (1998) reported that digestibility of DM in the rumen or in the total tract was similar for the diets containing an AS:AH of 33:67 or 67:33. Those researchers also observed that the digestibility of DM in the total tract was higher when feeding mixed AS and $\mathrm{AH}$ than when feeding $\mathrm{AS}$ or $\mathrm{AH}$ as sole forages, indicating an advantage for a silage and hay blend of that alfalfa forage. Nelson and Satter (1992b) reported that rates of digestion and passage were higher for silage than for hay. Higher digestibility of OM for silage than for hay has been observed by Broderick (1995). In this study, lack of increase in digestibility of OM with increased AS:AH was likely due to the trend toward a larger amount of OM digested in the rumen as a result of higher DMI with the high silage diet. 
Table 2. Intake, flow, and digestion of $\mathrm{OM}$ as affected by ratio of silage to hay or hay particle size in the diets of dairy cows.

\begin{tabular}{|c|c|c|c|c|c|c|c|c|}
\hline \multirow[b]{3}{*}{ Item } & \multicolumn{4}{|c|}{$\operatorname{Diets}^{1}$} & \multirow[b]{3}{*}{$\mathrm{SE}$} & \multicolumn{3}{|c|}{ Effect, ${ }^{2} P<$} \\
\hline & \multicolumn{2}{|c|}{ AS:AH 50:50 } & \multicolumn{2}{|c|}{ AS:AH 25:75 } & & \multirow[b]{2}{*}{ AS:AH } & \multirow[b]{2}{*}{ FPS } & \multirow{2}{*}{$\begin{array}{l}\text { AS:AH } \\
\times \text { FPS }\end{array}$} \\
\hline & $\mathrm{CH}$ & GH & $\mathrm{CH}$ & GH & & & & \\
\hline Intake, kg/d & 21.5 & 21.7 & 18.8 & 18.6 & 1.9 & 0.07 & $\mathrm{~ns}^{4}$ & $\mathrm{~ns}$ \\
\hline \multicolumn{9}{|l|}{ Flow, kg/d } \\
\hline \multicolumn{9}{|l|}{ Duodenal } \\
\hline Total & 13.1 & 12.1 & 11.8 & 10.5 & 1.6 & $\mathrm{~ns}$ & ns & $\mathrm{ns}$ \\
\hline Microbial & 2.85 & 2.37 & 2.85 & 2.14 & 0.43 & $\mathrm{~ns}$ & 0.13 & $\mathrm{~ns}$ \\
\hline Fecal & 6.6 & 7.1 & 6.2 & 6.4 & 0.7 & 0.14 & $\mathrm{~ns}$ & $\mathrm{~ns}$ \\
\hline \multicolumn{9}{|l|}{ Digestion } \\
\hline \multicolumn{9}{|l|}{ Ruminal } \\
\hline $\mathrm{RFOM},{ }^{3} \mathrm{~kg} / \mathrm{d}$ & 10.9 & 12.0 & 9.8 & 9.1 & 1.0 & 0.06 & $\mathrm{~ns}$ & $\mathrm{~ns}$ \\
\hline$\%$ of intake (true) & 53.5 & 56.6 & 52.1 & 52.1 & 2.7 & $\mathrm{~ns}$ & $\mathrm{~ns}$ & $\mathrm{~ns}$ \\
\hline$\%$ of total digested & 77.0 & 81.3 & 78.3 & 80.6 & 3.0 & $\mathrm{~ns}$ & 0.14 & $\mathrm{~ns}$ \\
\hline \multicolumn{9}{|l|}{ Postruminal } \\
\hline$\%$ of intake & 30.3 & 23.8 & 29.3 & 23.9 & 2.5 & $\mathrm{~ns}$ & 0.07 & $\mathrm{~ns}$ \\
\hline$\%$ of flow to duodenum & 49.1 & 43.1 & 46.5 & 39.6 & 3.1 & $\mathrm{~ns}$ & 0.07 & $\mathrm{~ns}$ \\
\hline \multicolumn{9}{|l|}{ Total tract } \\
\hline$\%$ of intake & 69.0 & 67.4 & 66.5 & 65.5 & 1.8 & $\mathrm{~ns}$ & $\mathrm{~ns}$ & $\mathrm{~ns}$ \\
\hline
\end{tabular}

${ }^{1} \mathrm{AS}: \mathrm{AH}=$ Ratio of alfalfa silage to alfalfa hay; $\mathrm{CH}=$ chopped hay; $\mathrm{GH}=$ ground hay.

${ }^{2}$ FPS $=$ Forage particle size.

${ }^{3}$ Organic matter truly fermented in the rumen.

${ }^{4} \mathrm{~ns}=P>0.15$.

Decreasing the FPS by replacing chopped hay with ground hay in the diets of dairy cows had no effects on digestibilities of $\mathrm{OM}$ in the rumen and in the total tract, but tended $(P<0.07)$ to reduce the digestibility in the intestine, which was likely due to numerically higher microbial OM flow at the duodenum. The microbial OM is usually highly digestible. Lack of effect of FPS on digestibility of OM, especially in the rumen, contrasted to other reports (Belyea et al., 1989). However, in those studies AH was used as the sole forage and fed to cows separately from the concentrate. Thus, differences in particle size of those diets could be greater due to the higher proportion of $\mathrm{AH}$ compared with the diets used in the present study. Belyea et al. (1989) reported that digestibility of DM in the total tract was different for diets containing $\mathrm{AH}$ chopped at 31 and $100 \mathrm{~mm}$ but not for $\mathrm{AH}$ chopped at 31 and $63 \mathrm{~mm}$.

Starch. Intake of starch was greater for high silage than for low silage diets due to differences in DMI since diets were formulated with similar starch content (Table 3). Digestibility of starch in the rumen or in the total tract was not affected by the treatments. However, reducing FPS in the diets of cows decreased the digestibility of starch in the intestine, expressed either as percentage of intake $(P<0.10)$ or as a percentage of flow to the duodenum $(P<0.03)$. Lower starch digestibility in the intestine with reduced FPS was apparently due to numerically higher ruminal digestion. On average, $60 \%$ of digestible starch was digested in the rumen and about $40 \%$ digested in the intestine, indicating that digestibility of starch in the rumen in this study was relatively low compared with expectations for a barleybased diet with a processing index for rolled barley of $65 \%$. Yang et al. (2000) reported that $70.5 \%$ of the starch was digested in the rumen and $23.1 \%$ in the intestine. Low ruminal digestibility of starch was unexpected because barley grain is usually highly fermentable in the rumen when barley is adequately processed (Yang et al., 2000).

There was numerically more $(P<0.13)$ starch digested in the rumen and consequently less digested in the intestine with decreased FPS, indicating that reducing FPS in dairy cow diets can allow more starch to be digested in the rumen. Alternatively, increased FPS shifts starch digestion from the rumen to the intestine. In the present study, increasing starch digestion in the rumen by decreasing FPS decreased chewing time and lowered ruminal $\mathrm{pH}$ (data reported by Beauchemin et al., 2002). Low rumen $\mathrm{pH}$ is not favorable for fiber digestion and can shift fermentation type from fiber to starch. Thus, increasing FPS of dairy cow diets may favour fiber fermentation and shift starch digestion to the intestine by increasing chewing activity and rumen $\mathrm{pH}$. Shifting starch digestion by manipulating FPS has been also observed in another study (Yang et al., 2001). In that study, digestibility of starch in the total tract for cows fed a barley-based diet was not affected by FPS, but the relative proportion of starch 
Table 3. Intake, flow, and digestion of starch as affected by ratio of silage to hay or hay particle size in the diets of dairy cows.

\begin{tabular}{|c|c|c|c|c|c|c|c|c|}
\hline \multirow[b]{3}{*}{ Item } & \multicolumn{4}{|c|}{$\operatorname{Diets}^{1}$} & \multirow[b]{3}{*}{$\mathrm{SE}$} & \multicolumn{3}{|c|}{ Effect, ${ }^{2} P<$} \\
\hline & \multicolumn{2}{|c|}{ AS:AH 50:50 } & \multicolumn{2}{|c|}{ AS:AH 25:75 } & & \multirow[b]{2}{*}{ AS:AH } & \multirow[b]{2}{*}{ FPS } & \multirow{2}{*}{$\begin{array}{l}\text { AS:AH } \\
\times \text { FPS }\end{array}$} \\
\hline & $\mathrm{CH}$ & GH & $\mathrm{CH}$ & GH & & & & \\
\hline Intake, kg/d & 7.34 & 7.30 & 6.45 & 6.08 & 0.59 & 0.03 & $\mathrm{~ns}^{3}$ & $\mathrm{~ns}$ \\
\hline \multicolumn{9}{|l|}{ Flow, kg/d } \\
\hline Duodenal & 3.13 & 2.69 & 3.02 & 2.48 & 0.44 & $\mathrm{~ns}$ & 0.08 & $\mathrm{~ns}$ \\
\hline Fecal & 0.58 & 0.61 & 0.54 & 0.52 & 0.09 & $\mathrm{~ns}$ & $\mathrm{~ns}$ & ns \\
\hline \multicolumn{9}{|l|}{ Digestion } \\
\hline \multicolumn{9}{|l|}{ Ruminal } \\
\hline$\%$ of intake & 57.1 & 64.2 & 52.4 & 57.0 & 4.9 & $\mathrm{~ns}$ & ns & $\mathrm{ns}$ \\
\hline$\%$ of total digested & 61.9 & 69.5 & 57.3 & 63.0 & 4.4 & ns & 0.13 & $\mathrm{~ns}$ \\
\hline \multicolumn{9}{|l|}{ Postruminal } \\
\hline$\%$ of intake & 35.0 & 28.0 & 38.9 & 33.4 & 3.9 & $\mathrm{~ns}$ & 0.10 & 0.08 \\
\hline$\%$ of flow to duodenum & 80.7 & 76.9 & 81.8 & 76.7 & 1.6 & $\mathrm{~ns}$ & 0.03 & ns \\
\hline \multicolumn{9}{|l|}{ Total tract } \\
\hline$\%$ of intake & 92.0 & 91.8 & 91.3 & 91.3 & 1.2 & ns & $\mathrm{ns}$ & $\mathrm{ns}$ \\
\hline
\end{tabular}

${ }^{1} \mathrm{AS}: \mathrm{AH}=$ Ratio of alfalfa silage to alfalfa hay; $\mathrm{CH}$ = chopped hay; $\mathrm{GH}$ = ground hay.

${ }^{2} \mathrm{FPS}=$ Forage particle size .

${ }^{3} \mathrm{~ns}=P>0.15$.

digested in the rumen and in the intestine was altered. The extent of digestion of barley starch in the total tract is mainly affected by extent of barley rolling (Yang et al., 2000). Knowledge of dietary factors that change site of starch digestion can be applied to improve feed efficiency or to prevent the incidence of ruminal acidosis. In fact, on the one hand, increasing the amount of starch digested in the rumen provided more energy to steers than if the starch was digested in the small intestine (Taniguchi et al., 1995) and on the other hand, the incidence of acidosis in cows fed high concentrate diets can be reduced by shifting starch digestion from the rumen to the intestine.

Fiber. Intakes of NDF or ADF reflected $\mathrm{OM}$ intake as diets were formulated with the same fiber contents (Table 4). Duodenal flows and digestibilities of fiber were not affected by AS:AH. However, digestibility of $\mathrm{NDF}$ or ADF in the total tract was decreased by $15 \%$ with reducing FPS in the diets due to a consistent numerical reduction of fiber digestion both in the rumen and in the intestine. Lack of effect of AS:AH on digestibility conflicts with the results of Broderick (1995) who reported that digestibility of $\mathrm{NDF}$ or $\mathrm{ADF}$ in the total tract of dairy cows was higher for silage than for hay. However, in that study, low digestion of fiber for the hay-based diet was at least partially due to higher DMI. Nelson and Satter (1992a) observed that although digestion rate was faster, turnover time was shorter and potential digestible DM was lower for silage than for hay. In this study, digestibility of fiber in the total tract was not affected by the AS:AH, but amount of NDF or $\mathrm{ADF}$ digested in the total tract was increased by 11 or
$21 \%$, respectively, with increased AS:AH of the diets resulting from increased fiber intake.

Depression of fiber digestion by reducing FPS is in agreement with other reports (Belyea et al., 1985; Grant et al., 1990). Grant et al. (1990) observed that reduced FPS was associated with depressed rumen $\mathrm{pH}$ and decreased acetate:propionate ratios. Belyea et al. (1985) found that digestibilities of NDF and ADF of chopped $\mathrm{AH}$ were depressed by about 10 percentage units compared with long hay. Those workers concluded that good quality forage that has been chopped or ground usually is less digestible than the long form. The decreased digestibility usually is presumed to be from increased intake and passage rate (Shaver et al., 1988). In the present study, lower digestibility of fiber was not due to an intake effect since intake of OM or fiber was not different between chopped and ground hay. Depression of rumen $\mathrm{pH}$ associated with reduced FPS in the diets likely resulted in the reduction of fiber digestibility for the present study. Ruminal cellulolytic activity is compromised when ruminal $\mathrm{pH}$ drops below 6.2 based on in vitro studies (Russell and Wilson, 1996).

N Fractions. Since diets were designed to be isonitrogenous, intake of $\mathrm{N}$ reflected $\mathrm{OM}$ intake (Table 5). Although $\mathrm{N}$ intake was higher $(P<0.08)$ for high than for low silage diets, flows of total N or NAN were not significantly affected by the AS:AH, possibly due to substantial animal variation and higher NPN from silage which is poorly utilized in the rumen. Flows of feed $\mathrm{N}$ plus endogenous $\mathrm{N}$ and microbial $\mathrm{N}$ to the duodenum were about 50 and $45 \%$ of $\mathrm{N}$ intake, respectively, and were not affected by the AS:AH. The higher OM fer- 
Table 4. Intakes, flows, and digestion of fiber affected by ratio of silage to hay or hay particle size in the diets of dairy cows.

\begin{tabular}{|c|c|c|c|c|c|c|c|c|}
\hline \multirow[b]{3}{*}{ Item } & \multicolumn{4}{|c|}{$\operatorname{Diets}^{1}$} & \multirow[b]{3}{*}{$\mathrm{SE}$} & \multicolumn{3}{|c|}{ Effect, ${ }^{2} P<$} \\
\hline & \multicolumn{2}{|c|}{ AS:AH 50:50 } & \multicolumn{2}{|c|}{ AS:AH 25:75 } & & \multirow[b]{2}{*}{ AS:AH } & \multirow[b]{2}{*}{ FPS } & \multirow{2}{*}{$\begin{array}{l}\text { AS:AH } \\
\times \text { FPS }\end{array}$} \\
\hline & $\mathrm{CH}$ & GH & $\mathrm{CH}$ & GH & & & & \\
\hline \multicolumn{9}{|l|}{ NDF } \\
\hline $\begin{array}{l}\text { Intake, } \mathrm{kg} / \mathrm{d} \\
\text { Flow, kg/d }\end{array}$ & 8.56 & 7.83 & 7.29 & 6.82 & 0.80 & 0.06 & $\mathrm{~ns}^{3}$ & $\mathrm{~ns}$ \\
\hline Duodenal & 5.11 & 5.05 & 4.42 & 4.10 & 0.67 & 0.13 & $\mathrm{~ns}$ & $\mathrm{~ns}$ \\
\hline Fecal & 4.13 & 4.59 & 3.56 & 3.72 & 0.49 & 0.03 & $\mathrm{~ns}$ & $\mathrm{~ns}$ \\
\hline \multicolumn{9}{|l|}{ Digestion } \\
\hline \multicolumn{9}{|l|}{ Ruminal } \\
\hline$\%$ of intake & 39.1 & 37.0 & 40.3 & 35.5 & 3.8 & $\mathrm{~ns}$ & $\mathrm{~ns}$ & $\mathrm{~ns}$ \\
\hline$\%$ of total digested & 73.0 & 79.9 & 78.1 & 82.5 & 7.5 & $\mathrm{~ns}$ & $\mathrm{~ns}$ & $\mathrm{~ns}$ \\
\hline \multicolumn{9}{|l|}{ Postruminal } \\
\hline$\%$ of intake & 14.4 & 9.6 & 11.3 & 7.7 & 3.9 & $\mathrm{~ns}$ & $\mathrm{~ns}$ & $\mathrm{~ns}$ \\
\hline$\%$ of flow to duodenum & 22.7 & 16.0 & 17.6 & 11.2 & 5.5 & $\mathrm{~ns}$ & $\mathrm{~ns}$ & $\mathrm{~ns}$ \\
\hline$\%$ of total digested & 29.5 & 21.6 & 21.9 & 22.8 & 8.9 & $\mathrm{~ns}$ & $\mathrm{~ns}$ & $\mathrm{~ns}$ \\
\hline \multicolumn{9}{|l|}{ Total tract } \\
\hline$\%$ of intake & 51.1 & 41.7 & 51.6 & 45.5 & 3.6 & $\mathrm{~ns}$ & 0.02 & $\mathrm{~ns}$ \\
\hline \multicolumn{9}{|l|}{$\mathrm{ADF}$} \\
\hline $\begin{array}{l}\text { Intake, kg/d } \\
\text { Flow, kg/d }\end{array}$ & 6.71 & 6.03 & 5.45 & 5.06 & 0.62 & 0.02 & $\mathrm{~ns}$ & $\mathrm{~ns}$ \\
\hline Duodenal & 3.55 & 3.56 & 3.16 & 2.88 & 0.39 & 0.13 & $\mathrm{~ns}$ & $\mathrm{~ns}$ \\
\hline Fecal & 3.02 & 3.33 & 2.56 & 2.70 & 0.37 & 0.04 & $\mathrm{~ns}$ & $\mathrm{~ns}$ \\
\hline \multicolumn{9}{|l|}{ Digestion } \\
\hline \multicolumn{9}{|l|}{ Ruminal } \\
\hline$\%$ of intake & 45.2 & 40.5 & 41.3 & 39.1 & 2.9 & $\mathrm{~ns}$ & ns & $\mathrm{ns}$ \\
\hline$\%$ of total digested & 80.3 & 85.4 & 77.7 & 85.8 & 4.6 & $\mathrm{~ns}$ & 0.09 & $\mathrm{~ns}$ \\
\hline \multicolumn{9}{|l|}{ Postruminal } \\
\hline$\%$ of intake & 11.4 & 7.0 & 11.9 & 7.5 & 2.8 & $\mathrm{~ns}$ & 0.06 & $\mathrm{~ns}$ \\
\hline$\%$ of flow to duodenum & 21.1 & 11.9 & 20.0 & 13.1 & 5.2 & ns & 0.05 & ns \\
\hline Total tract & & & & & & & & \\
\hline$\%$ of intake & 54.2 & 45.3 & 53.2 & 46.5 & 4.4 & $\mathrm{~ns}$ & 0.03 & $\mathrm{~ns}$ \\
\hline
\end{tabular}

${ }^{1} \mathrm{AS}: \mathrm{AH}=$ Ratio of alfalfa silage to alfalfa hay; $\mathrm{CH}=$ chopped hay; $\mathrm{GH}=$ ground hay.

${ }^{2} \mathrm{FPS}=$ Forage particle size .

${ }^{3} \mathrm{~ns}=P>0.15$.

mented in the rumen with the high silage diet did not support higher microbial protein synthesis. Peltekova and Broderick (1996) reported that in vitro microbial protein synthesis for AH was $33 \%$ greater than for AS. Hristov and Broderick (1996) also found that, compared with $\mathrm{AH}$, less degraded $\mathrm{CP}$ from $\mathrm{AS}$ was recovered as net microbial protein synthesized in the rumen of dairy cows. Greater net formation of microbial protein for $\mathrm{AH}$ might be attributed to preferential utilization of $\mathrm{AA}$ and peptides by ruminal microorganisms when $\mathrm{NH}_{3}$ is in excess (Wallace and Cotta, 1988).

Although intake of $\mathrm{N}$ and flows of total N, NAN, or feed $\mathrm{N}$ plus endogenous $\mathrm{N}$ were not affected by the FPS, flow of microbial $\mathrm{N}$ to the duodenum was decreased $(P$ $<0.11$ ) by $22 \%$ with reduced FPS. Because the amount of nutrients fermented in the rumen was not different for chopped or ground $\mathrm{AH}$, lower rumen $\mathrm{pH}$ with ground $\mathrm{AH}$ as observed previously (Beauchemin et al., 2002) resulted in the reduction of microbial protein synthesis. The present results are opposite to the results of Rode et al. (1985), who found greater NAN, feed N, and micro- bial $\mathrm{N}$ flows to the duodenum with ground than with chopped $\mathrm{AH}$, and greater solids turnover rate for ground hay apparently was causative in increasing $\mathrm{N}$ flow.

Efficiency of microbial protein synthesis (grams microbial $\mathrm{N}$ per kilogram of $\mathrm{OM}$ truly digested in the rumen) was not different between high and low silage diets and was greater for chopped hay (26.9) than for ground hay (21.8). Greater efficiency of microbial protein synthesis was attributed to higher outflow rate based on the findings of Rode et al. (1985). Microbial efficiency was positively related to solids turnover rate and negatively related to liquid turnover rate when $\mathrm{AH}$ of different particle sizes were fed; when solids turnover rate was unaffected by diet, microbial efficiency was positively related to liquid turnover rate (Rode et al., 1985). Improvement in microbial efficiency with chopped hay might be due to increased rumination activity with chopped hay (Beauchemin et al., 2002). Rumination detaches microorganisms from feed particles into rumen fluid and allows them with greater outflow rate to leave from the rumen with liquid. 
Table 5. Intake, flows, and digestion of nitrogen affected by ratio of silage to hay or hay particle size in the diets of dairy cows.

\begin{tabular}{|c|c|c|c|c|c|c|c|c|}
\hline \multirow[b]{3}{*}{ Item } & \multicolumn{4}{|c|}{$\operatorname{Diets}^{1}$} & \multirow[b]{3}{*}{$\mathrm{SE}$} & \multicolumn{3}{|c|}{ Effect, ${ }^{2} P<$} \\
\hline & \multicolumn{2}{|c|}{ AS:AH 50:50 } & \multicolumn{2}{|c|}{ AS:AH 25:75 } & & \multirow[b]{2}{*}{ AS:AH } & \multirow[b]{2}{*}{ FPS } & \multirow{2}{*}{$\begin{array}{l}\text { AS:AH } \\
\times \text { FPS }\end{array}$} \\
\hline & $\mathrm{CH}$ & GH & $\mathrm{CH}$ & GH & & & & \\
\hline Intake, g/d & 627.4 & 583.0 & 559.6 & 506.4 & 53.0 & 0.08 & $\mathrm{~ns}^{5}$ & $\mathrm{~ns}$ \\
\hline \multicolumn{9}{|l|}{ Flow to duodenum } \\
\hline \multicolumn{9}{|l|}{ Total } \\
\hline $\mathrm{g} / \mathrm{d}$ & 607.7 & 541.3 & 546.7 & 473.6 & 73.3 & $\mathrm{~ns}$ & $\mathrm{~ns}$ & $\mathrm{~ns}$ \\
\hline$\%$ of intake & 96.5 & 92.5 & 97.4 & 98.1 & 4.8 & $\mathrm{~ns}$ & $\mathrm{~ns}$ & $\mathrm{~ns}$ \\
\hline \multicolumn{9}{|l|}{$\mathrm{NAN}^{3}$} \\
\hline $\mathrm{g} / \mathrm{d}$ & 603.8 & 537.5 & 542.7 & 469.7 & 72.6 & $\mathrm{~ns}$ & $\mathrm{~ns}$ & $\mathrm{~ns}$ \\
\hline$\%$ of intake & 95.8 & 91.8 & 96.7 & 97.3 & 4.9 & $\mathrm{~ns}$ & $\mathrm{~ns}$ & $\mathrm{~ns}$ \\
\hline \multicolumn{9}{|l|}{ Feed + endogenous } \\
\hline $\mathrm{g} / \mathrm{d}$ & 321.9 & 302.4 & 270.3 & 277.8 & 42.1 & $\mathrm{~ns}$ & $\mathrm{~ns}$ & $\mathrm{~ns}$ \\
\hline$\%$ of intake & 51.1 & 52.5 & 49.0 & 58.1 & 4.0 & $\mathrm{~ns}$ & $\mathrm{~ns}$ & $\mathrm{~ns}$ \\
\hline \multicolumn{9}{|l|}{ Microbial } \\
\hline $\mathrm{g} / \mathrm{d}$ & 273.8 & 226.2 & 272.3 & 198.7 & 41.0 & $\mathrm{~ns}$ & 0.11 & $\mathrm{~ns}$ \\
\hline$\%$ of intake & 44.8 & 38.9 & 47.7 & 40.4 & 5.7 & $\mathrm{~ns}$ & $\mathrm{~ns}$ & $\mathrm{~ns}$ \\
\hline $\mathrm{g} / \mathrm{kg}$ of $\mathrm{RFOM}^{4}$ & 24.9 & 18.2 & 26.9 & 21.2 & 2.6 & ns & 0.02 & $\mathrm{~ns}$ \\
\hline Fecal, g/d & 214.9 & 218.9 & 202.5 & 187.5 & 25.7 & $\mathrm{~ns}$ & $\mathrm{~ns}$ & $\mathrm{~ns}$ \\
\hline \multicolumn{9}{|l|}{ Digestibility } \\
\hline Ruminal (truly) \% & 48.9 & 47.5 & 51.0 & 41.9 & 3.9 & $\mathrm{~ns}$ & $\mathrm{~ns}$ & $\mathrm{~ns}$ \\
\hline \multicolumn{9}{|l|}{ Postruminal } \\
\hline$\%$ of intake & 63.3 & 56.1 & 61.9 & 60.2 & 4.6 & $\mathrm{~ns}$ & $\mathrm{~ns}$ & $\mathrm{~ns}$ \\
\hline$\%$ of flow to duodenum & 65.0 & 60.4 & 63.0 & 60.6 & 2.1 & $\mathrm{~ns}$ & 0.02 & $\mathrm{~ns}$ \\
\hline Total tract, $\%$ of intake & 65.9 & 62.8 & 64.5 & 62.8 & 1.7 & $\mathrm{~ns}$ & 0.12 & $\mathrm{~ns}$ \\
\hline
\end{tabular}

${ }^{1} \mathrm{AS}: \mathrm{AH}=$ Ratio of alfalfa silage to alfalfa hay; $\mathrm{CH}=$ chopped hay; $\mathrm{GH}=$ ground hay.

${ }^{2}$ FPS $=$ Forage particle size .

${ }^{3}$ Nonammonia N.

${ }^{4}$ Organic matter truly digested in the rumen.

${ }^{5} \mathrm{~ns}=P>0.15$.

Ruminal digestibility of $\mathrm{N}$ was not affected by the treatments. Peltekova and Broderick (1996) found that there were no significant differences between $\mathrm{AH}$ and $\mathrm{AS}$ in degradation rate and ruminal protein escape. Protein in AS was numerically less degradable than that in AH despite the higher NPN content of AS (Peltekova and Broderick, 1996). Digestibility of $\mathrm{N}$ in the intestine was not different when expressed as a percentage of $\mathrm{N}$ intake, while digestibility, expressed as a percentage of $\mathrm{N}$ flow to duodenum, was higher with chopped hay than with ground hay. Numerically higher $(P<0.14)$ proportion of microbial $\mathrm{N}$ in the duodenal flow of NAN for chopped hay (49.5\%) than for ground hay (44.8\%) may explain the difference of the intestinal $\mathrm{N}$ digestibility because microbial $\mathrm{N}$ is usually more highly digestible than escaped feed $\mathrm{N}$, especially for forage $\mathrm{N}$ (NRC, 2001). Digestion of $\mathrm{N}$ in the total tract increased with increased the FPS $(P<0.12)$, due to numerically higher $\mathrm{N}$ digestibility in the rumen and significantly higher digestibility of $\mathrm{N}$ in the intestine with chopped hay than with ground hay.

\section{Ruminal Pools and Passage Rates}

Ruminal pools. Ruminal wet mass was constant with changing AS:AH and decreased by $17 \%$ with de- creased FPS (Table 6). The proportion of liquid in the rumen contents, which averaged $46 \%$ and was determined by manually squeezing through four layers of cheesecloth, was not affected by diet. There were numerical interactions $(P<0.15)$ between AS:AH and FPS for ruminal pools of DM, OM, and NDF. For high silage diets, feeding ground hay rather than chopped hay reduced the ruminal pool size. However, for low silage diets, there were no effects of FPS on ruminal pool size of nutrients even though wet mass was significantly lower with ground hay, indicating that rumen contents with chopped hay diet have a greater capacity to imbibe water. The present results are in agreement with the observation of Phuntsok et al. (1998) in which a diet containing more moisture did not increase ruminal liquid contents. In fact, in our study, the diet that contained low silage with chopped hay had the highest ruminal moisture content ( 85.7 vs. $83.9,84.5$, or $83.5 \%$ for other three diets), likely due to more rumination and salivation during ingestion and swallowing (Beauchemin et al., 2001). Ruminal mean $\mathrm{pH}$ was also highest (6.18) for this diet (Beauchemin et al., 2002). It appeared that rumen fill does not have a major role in limiting DMI for high quality forage diets, but high DM content of feed may contribute to intake depression. 
Table 6. Pools and passage rates $^{1}$ of rumen contents affected by ratio of silage to hay or hay particle size in the diets of dairy cows.

\begin{tabular}{|c|c|c|c|c|c|c|c|c|}
\hline \multirow[b]{3}{*}{ Item } & \multicolumn{4}{|c|}{$\operatorname{Diets}^{2}$} & \multirow[b]{3}{*}{ SE } & \multicolumn{3}{|c|}{ Effect, ${ }^{3} P<$} \\
\hline & \multicolumn{2}{|c|}{ AS:AH 50:50 } & \multicolumn{2}{|c|}{ AS:AH 25:75 } & & \multirow[b]{2}{*}{ AS:AH } & \multirow[b]{2}{*}{ FPS } & \multirow{2}{*}{$\begin{array}{l}\text { AS:AH } \\
\times \text { FPS }\end{array}$} \\
\hline & $\mathrm{CH}$ & GH & $\mathrm{CH}$ & GH & & & & \\
\hline \multicolumn{9}{|l|}{ Rumen pools, kg } \\
\hline Wet contents & 82.8 & 68.5 & 82.3 & 68.3 & 4.4 & $\mathrm{~ns}^{7}$ & 0.02 & $\mathrm{~ns}$ \\
\hline Liquid, ${ }^{4} \%$ of wet content & 45.3 & 46.8 & 46.8 & 45.0 & 2.5 & $\mathrm{~ns}$ & $\mathrm{~ns}$ & $\mathrm{~ns}$ \\
\hline $\mathrm{DM}$ & 13.3 & 10.6 & 11.8 & 11.3 & 1.1 & $\mathrm{~ns}$ & 0.09 & ns \\
\hline OM & 12.0 & 9.4 & 10.4 & 10.1 & 0.9 & ns & 0.07 & 0.13 \\
\hline $\mathrm{NDF}$ & 8.1 & 6.4 & 7.0 & 6.6 & 0.6 & ns & 0.03 & 0.14 \\
\hline $\mathrm{N}, \mathrm{g}$ & 370.9 & 292.7 & 332.2 & 311.4 & 31.8 & ns & 0.14 & ns \\
\hline \multicolumn{9}{|l|}{ Microbial pool } \\
\hline $\mathrm{DM}, \%$ of rumen DM & 17.3 & 20.6 & 20.7 & 18.9 & 1.4 & ns & $\mathrm{ns}$ & 0.07 \\
\hline $\mathrm{N}, \%$ of rumen $\mathrm{N}$ & 46.4 & 55.9 & 55.0 & 49.5 & 3.4 & ns & ns & 0.05 \\
\hline \multicolumn{9}{|l|}{ Passage rate } \\
\hline $\mathrm{LORR}^{5}, \% / \mathrm{h}$ & 9.0 & 8.8 & 7.7 & 5.9 & 1.3 & 0.06 & $\mathrm{~ns}$ & $\mathrm{~ns}$ \\
\hline \multicolumn{9}{|l|}{ Forage } \\
\hline $\mathrm{PORR}^{6}, \% / \mathrm{h}$ & 4.1 & 4.0 & 2.8 & 3.3 & 0.6 & 0.03 & $\mathrm{~ns}$ & $\mathrm{~ns}$ \\
\hline Transit time, $\mathrm{h}$ & 8.8 & 10.8 & 9.5 & 10.0 & 0.5 & $\mathrm{~ns}$ & 0.03 & 0.14 \\
\hline Ruminal retention time, $\mathrm{h}$ & 25.2 & 29.1 & 39.7 & 31.5 & 5.0 & 0.04 & ns & 0.11 \\
\hline Mean retention time, $\mathrm{h}$ & 42.7 & 37.3 & 50.8 & 40.8 & 4.2 & 0.05 & 0.02 & $\mathrm{~ns}$ \\
\hline
\end{tabular}

${ }^{1}$ Markers: liquid, Co-EDTA; solids, Cr-mordanted NDF. The two-compartmental fecal model of Grovum and Williams (1973) was used for calculation.

${ }^{2} \mathrm{AS}: \mathrm{AH}=$ Ratio of alfalfa silage to alfalfa hay; $\mathrm{CH}=$ chopped hay; $\mathrm{GH}=$ ground hay

${ }^{3} \mathrm{FPS}=$ Forage particle size.

${ }^{4}$ Separated by squeezing through four layers cheesecloth.

${ }^{5}$ Liquid outflow rate from the reticulo-rumen.

${ }^{6}$ Particulate outflow rate from the reticulo-rumen.

${ }^{7} \mathrm{~ns}=P>0.15$.

Clancy et al. (1977) found that cows consumed less DM when dried AS rather than wet hay was fed.

The size of the ruminal microbial pool, expressed as percentage of microbial $\mathrm{DM}$ or $\mathrm{N}$ in the total ruminal $\mathrm{DM}$ or N, ranged from 17.3 to $20.7 \%$ for DM and 46.4 to $55.9 \%$ for $\mathrm{N}$, and were not affected by the treatments. However, there was an interaction of AS:AH $\times$ FPS $(P$ $<0.07)$ for the microbial materials present in the total rumen contents. With the high silage diet, microbial pools increased $(P<0.10)$ as FPS decreased, and with low silage diet, microbial pools numerically decreased as FPS decreased.

Passage rates. Passage rates of rumen liquid and solids were higher $(P<0.07)$ for high silage than for low silage diets (Table 6$)$. Thus, retention time of solids in the rumen $(P<0.08)$ or in the total tract $(P<0.11)$ was lower for the high silage versus low silage diet. Longer ruminal retention time has been observed for hay relative to silage in lactating cows (Nelson and Satter, 1992a); ruminal retention time averaged $6.3 \mathrm{~h}$ longer for hay diets than for silage diets. In our study the passage rate of liquid out of the rumen was particularly slow for the low silage diet containing ground hay. This may be due to the relative lack of mat or raft formation in the dorsal rumen, which was observed consistently during sampling and manually rumen evacuations.

Decreased FPS did not affect ruminal passage rates of liquid or solid, but decreased retention time in the total tract. Similarly, Rode et al. (1985) demonstrated that ground hay relative to chopped hay increased solids turnover rate. This might partially explain the present results of lower fiber digestion in the total tract due to reduced FPS.

\section{Effects of Dietary Content of peNDF}

The proportion of peNDF of the diets was estimated based on particle size and NDF content of the diets and calculated using different methods (Table 7). The AS:AH and FPS significantly affected intake of peNDF since particle size and NDF content of the AS and AH were different (Beauchemin et al., 2002). Proportion of peNDF $_{M}$ estimated from the table of Mertens (1997) and peNDF ${ }_{P>1.18}$ estimated from the particles retained on a $1.18-\mathrm{mm}$ screen, in the diets (DM basis) varied from 18.3 to $26.7 \%$ of $\mathrm{DM}$, which was in the range of the minimum recommendation. Mertens (2000) recommended that $19.7 \%$ peNDF was needed to maintain a milk fat percentage at $3.4 \%$ for Holstein cows, and 
Table 7. Particle size distribution and physical effectiveness factors (pef) of diets.

\begin{tabular}{|c|c|c|c|c|c|c|c|c|}
\hline \multirow[b]{3}{*}{ Item } & \multicolumn{4}{|c|}{$\operatorname{Diets}^{1}$} & \multirow[b]{3}{*}{$\mathrm{SE}$} & \multicolumn{3}{|c|}{ Effect, ${ }^{2} P<$} \\
\hline & \multicolumn{2}{|c|}{ AS:AH 50:50 } & \multicolumn{2}{|c|}{ AS:AH 25:75 } & & \multirow[b]{2}{*}{ AS:AH } & \multirow[b]{2}{*}{ FPS } & \multirow{2}{*}{$\begin{array}{l}\mathrm{AS}: \mathrm{AH} \\
\times \text { FPS }\end{array}$} \\
\hline & $\mathrm{CH}$ & GH & $\mathrm{CH}$ & GH & & & & \\
\hline \multicolumn{9}{|l|}{ pef, $\%$} \\
\hline $\operatorname{pef}_{\mathrm{PS}}^{3}$ & 41.3 & 30.7 & 37.7 & 21.9 & 2.1 & 0.02 & 0.01 & $\mathrm{~ns}^{10}$ \\
\hline $\operatorname{pef}_{M}^{4}$ & 67.5 & 59.7 & 66.8 & 55.0 & & & & $\ldots$ \\
\hline $\operatorname{pef}_{P>1.18^{5}}$ & 73.5 & 63.6 & 68.8 & 59.4 & 1.2 & 0.02 & 0.01 & ns \\
\hline \multicolumn{9}{|l|}{ Intake of peNDF ${ }^{6}, \%$ of DMI } \\
\hline $\operatorname{peNDF}_{\mathrm{PS}}^{7}$ & 15.0 & 10.1 & 13.3 & 7.2 & 0.8 & 0.02 & 0.01 & ns \\
\hline $\operatorname{peNDF}_{M}^{8}$ & 24.5 & 19.6 & 23.6 & 18.3 & 0.4 & 0.02 & 0.01 & $\mathrm{~ns}$ \\
\hline $\operatorname{peNDF}_{P}>1.18^{9}$ & 26.7 & 20.9 & 24.3 & 19.7 & 0.3 & 0.01 & 0.01 & 0.01 \\
\hline
\end{tabular}

${ }^{1} \mathrm{AS}: \mathrm{AH}=$ Ratio of alfalfa silage to alfalfa hay; $\mathrm{CH}=$ chopped hay; $\mathrm{GH}=$ ground hay.

${ }^{2}$ FPS $=$ Forage particle size.

${ }^{3}$ Physical effectiveness factor determined as the proportion of dry matter retained by both sieves of the Penn State Particle Separator.

${ }^{4}$ Physical effectiveness factor determined from the table of Mertens (1997). The pef of steam-rolled barley was assumed to be $70 \%$.

${ }^{5}$ Physical effectiveness factor determined as a percent of DM remaining on a $1.18 \mathrm{~mm}$ screen.

${ }^{6}$ Physically effective NDF.

${ }^{7}$ Physically effective NDF measured as the NDF content multiplied by pef $f_{\mathrm{PS}}$.

${ }^{8}$ Physically effective NDF measured as the NDF content multiplied by pef $_{\mathrm{M}}$.

${ }^{9}$ Physically effective NDF measured as the NDF content multiplied by $\operatorname{pef}_{P>1.18}$.

${ }^{10} \mathrm{~ns}=P>0.15$.

$22.3 \%$ peNDF was needed to maintain an average ruminal $\mathrm{pH}$ of 6.0. However, the proportion of peNDF $\mathrm{PS}_{\text {, }}$ estimated by multiplying NDF content by the proportion of DM retained by both sieves of the PSPS, ranged only from 7.2 to $15 \%$ of the diet DM. Furthermore, regardless of the AS:AH, the diets containing chopped hay had similar peNDF ${ }_{\mathrm{M}}$ or $\mathrm{peNDF}_{P>1.18}$ (around $24 \%$ ), while the diets contained ground hay had similar peNDF $_{M}$ and peNDF ${ }_{P>1.18}$ (about 19\%).

It is apparent that peNDF did not influence intake of nutrients. The feed intake varied with the AS:AH rather than with the FPS or proportion of the peNDF of the diets. However, the proportion of peNDF, either peNDF $_{\mathrm{M}}$ or peNDF $\mathrm{F}_{P>1.18}$, of the diets was moderately correlated to the digestibility of NDF and $\mathrm{N}$ in the total tract ( $\mathrm{r}=0.50, P<0.08$ ), but not to ruminal digestion. For instance, the digestibility of NDF in the total tract was on average 51.4 and $43.6 \%$ for diets containing 24 and $19 \%$ peNDF $_{\mathrm{M}}$, respectively. Similarly, digestibility of $\mathrm{N}$ in the total tract was 65.2 and $62.8 \%$ for diets containing 24 and $19 \%$ peNDF $_{\mathrm{M}}$, respectively. Failure to detect a correlation between the peNDF and ruminal digestibility could be due to high animal variation when measuring ruminal digestion. The present result is in agreement with our previous observation that increasing the proportion of peNDF of the diets improved rumen $\mathrm{pH}$ status which is favorable to ruminal fiber digestion. There was also a positive correlation for the proportion of the peNDF in the diets with ruminal microbial protein synthesis $(\mathrm{r}=0.49, P<0.09)$ and microbial efficiency $(\mathrm{r}=0.60, P<0.03)$ when the peNDF was estimated using the method of Mertens or particles retained on a 1.18-mm screen rather than the peNDF ${ }_{\mathrm{PS}}$. Ruminal microbial protein represented from 45 to $48 \%$ or from 39 to $40 \%$ of ingested protein for diets contained 23 or $19 \%$ peNDF, respectively. However, in another study (Yang et al., 2001), changing peNDF content of diet by manipulating forage particle size did not affect the production of ruminal microbial protein, probably because in that study the lowest proportion of peNDF (21\%) was near the minimum recommendation, and ruminal $\mathrm{pH}$ and digestibility of fiber were not affected by the peNDF content. These data suggests that the proportion of dietary peNDF is a reliable predictor of ruminal microbial protein synthesis and fiber digestion, but further study is warranted to investigate optimal peNDF content in dairy cow diets. In addition, methods for determining peNDF content of diets also need to be standardized.

\section{CONCLUSIONS}

Manipulating the ratio of $\mathrm{AS}$ and $\mathrm{AH}$ in the diets of dairy cows significantly changed feed intake, but had little effect on nutrient digestion. In contrast, increased FPS of the dairy cow diets improved fiber digestion and microbial protein synthesis in the rumen with no effect on feed intake. Increasing the FPS of the diets shifted 
starch digestion from the rumen to the intestine. Lower ruminal starch digestion may help to prevent ruminal acidosis in cows fed highly fermentable barley-based diets.

Dietary particle size, expressed as peNDF, was a reliable predictor of ruminal microbial protein synthesis and fiber digestion, but further study is warranted to investigate optimal peNDF content in dairy cow diets. In addition, methods for determining peNDF content of diets also need to be standardized.

\section{ACKNOWLEDGMENTS}

This experiment was financially supported by the Alberta Milk Producers (Edmonton, AB), the Canada/ Alberta Livestock Research Trust (Lethbridge, AB), and Agriculture and Agri-Food Canada's Matching Investment Initiative. The authors thank K. Andrews, G. Bowman, J. Chang, S. Eivemark, J. Erickson, B. Farr, C. Holmes, L. Madge, D. Vedres, and A. Zook for their assistance in performing laboratory analyses and the staff of the Lethbridge Research Centre dairy unit for care of the cows and milk sample collection.

\section{REFERENCES}

Allen, M. S. 1997. Relationship between fermentation acid production in the rumen and the requirement for physically effective fiber. J. Dairy Sci. 80:1447-1462.

Association of Official Analytical Chemists. 1990. Official Methods of Analysis. Vol. I. 15th ed. AOAC, Arlington, VA.

Beauchemin, K. A., and J. G. Buchanan-Smith. 1989. Effects of dietary neutral detergent fiber concentration and supplementary long hay on chewing activities and milk production of dairy cows. J. Dairy Sci. 72:2288-2300.

Beauchemin, K. A., B. I. Farr, L. M. Rode, and G. B. Schaalje. 1994. Effects of alfalfa silage chop length and supplementary long hay on chewing and milk production of dairy cows. J. Dairy Sci. 77:1326-1339.

Beauchemin, K. A., W. Z. Yang, and L. M. Rode. 2002. Effects of particle size of alfalfa-based dairy cow diets on chewing activity, ruminal fermentation and milk production. J. Dairy Sci. (Accepted).

Belyea, R. L., F. A. Martz, and G. A. Mbagaya. 1989. Effect of particle size of alfalfa hay on intake, digestibility, milk yield, and ruminal cell wall of dairy cattle. J. Dairy Sci. 72:958-963.

Belyea, R. L., P. J. Martin, and H. T. Sedgwick. 1985. Utilization of chopped and long alfalfa for dairy cows. J. Dairy Sci. 68:12971301.

Broderick, G. A. 1995. Performance of lactating dairy cows fed either alfalfa silage or alfalfa hay as the sole forage. J. Dairy Sci. 78:320-329.

Clancy, M., P. J. Wangness, and B. R. Baumgardt. 1977. Effect of conservation method on digestibility, nitrogen balance, and intake of alfalfa. J. Dairy Sci. 60:572-579.

Grant, R. J., V. F. Colenbrander, and D. R. Mertens. 1990. Milk fat depression in dairy cows: Role of particle size of alfalfa hay. J. Dairy Sci. 73:1823-1833.

Grovum, W. L., and V. J. Williams. 1973. Rate of passage of digesta in sheep. 4. Passage of marker through the alimentary tract and the biological relevance of rate-constants derived from the changes in concentration of marker in faeces. Br. J. Nutr. 30:313-329.

Hristov, A. N., and G. A. Broderick. 1996. Synthesis microbial protein in ruminally cannulated cows fed alfalfa silage, alfalfa hay, or corn silage. J. Dairy Sci. 79:1627-1637.

Lammers, B. P., D. R. Buckmaster, and A. J. Heinrichs. 1996. A simple method for the analysis of particle sizes of forage and total mixed rations. J. Dairy Sci. 79:922-928.

Mertens, D. R. 1997. Creating a system for meeting the fiber requirements of dairy cows. J. Dairy Sci. 80:1463-1481.

Mertens, D. R. 2000. Physically effective NDF and its use in dairy rations explored. Feedstuffs. Pages 11-14, April 10, 2000.

Murphy, M. R., and J. S. Zhu. 1997. A comparison of methods to analyze particle size as applied to alfalfa haylage, corn silage, and concentrate mix. J. Dairy Sci. 80:2932-2938.

National Research Council. 1989. Nutrient Requirements of Dairy Cattle. 6th rev. ed. Natl. Acad. Sci., Washington, DC.

National Research Council. 2001. Nutrient Requirements of Dairy Cattle. 7th rev. ed. Natl. Acad. Sci., Washington, DC.

Nelson, W. F., and L. D. Satter. 1992a. Impact of alfalfa maturity and preservation method on milk production by cows in early lactation. J. Dairy Sci. 75:1562-1570.

Nelson, W. F., and L. D. Satter. 1992b. Impact of stage of maturity and method of preservation of alfalfa on digestion in lactating dairy cows. J. Dairy Sci. 75:1571-1580.

Peltekova, V. D., and G. A. Broderick. 1996. In vitro ruminal degradation and synthesis of protein on fractions extracted from alfalfa hay and silage. J. Dairy Sci. 79:612-619.

Phuntsok, T., M. A. Froetschel, H. E. Amos, M. Zheng, and Y. W. Huang. 1998. Biogenic amines in silage, apparent postruminal passage, and the relationship between biogenic amines and digestive function and intake by steers. J. Dairy Sci. 81:2193-2203.

Rode, L. M., D. C. Weakley, and L. D. Satter.1985. Effect of forage amount and particle size in diets of lactating dairy cows on site of digestion and microbial protein synthesis. Can. J. Anim. Sci. 65:101-111.

Rode, L. M., W. Z. Yang, and K. A. Beauchemin. 1999. Fibrolytic enzyme supplements for dairy cows in early lactation. J. Dairy Sci. 82:2121-2126.

Russell, J. B., and D. B. Wilson. 1996. Why are ruminal cellulolytic bacteria unable to digest cellulose at low $\mathrm{pH}$ ? J. Dairy Sci. 79:1503-1509.

SAS User's Guide: Statistics, Version 7 Edition. 1996. SAS Inst., Inc., Cary, NC.

Shaver, R. D., L. D. Satter, and N. A. Jorgensen. 1988. Impact of forage fiber content on digestion and passage in dairy cows. J. Dairy Sci. 71:1556-1565.

Taniguchi, K., G. B. Huntington, and B. P. Glenn. 1995. Net nutrient flux by visceral tissues of beef steers given abomasal and ruminal infusions of casein and starch. J. Anim. Sci. 73:236-249.

Udén, P., P. E. Colucci, and P. J. Van Soest. 1980. Investigation of chromium, cerium, and cobalt as markers in digesta. Rate of passage studies. J. Sci. Food Agric. 31:625-632.

Van Soest, P. J., J. B. Robertson, and B. A. Lewis. 1991. Methods for dietary fiber, neutral detergent fiber and non-starch polysaccharide in relation to animal nutrition. J. Dairy Sci. 74:35833597.

Wallace, R. J., and M. A. Cotta. 1988. Metabolism of nitrogen containing compunds. Page 217 in The Rumen Microbial Ecosystem. P. N. Hobson, ed. Elsevier, London.

Yang, W. Z., K. A. Beauchemin, and L. M. Rode. 2000. Effects of barley grain processing on extent of digestion and milk production of lactating cows. J. Dairy Sci. 83:554-568.

Yang, W. Z., K. A. Beauchemin, and L. M. Rode. 2001. Effects of grain processing, forage to concentrate ratio, and forage particle size on rumen $\mathrm{pH}$ and digestion by dairy cows. J. Dairy Sci $84: 2203-2216$. 